\title{
Book Review: Mothering the Fatherland: A Protestant Sisterhood Repents for the Holocaust
}

Linda F. Burghardt

Holocaust Memorial \& Tolerance Center

Follow this and additional works at: https://digitalcommons.usf.edu/gsp

\section{Recommended Citation}

Burghardt, Linda F. (2016) "Book Review: Mothering the Fatherland: A Protestant Sisterhood Repents for the Holocaust," Genocide Studies and Prevention: An International Journal: Vol. 9: Iss. 3: 188-190.

DOI:

http://dx.doi.org/10.5038/1911-9933.9.3.1394

Available at: https://digitalcommons.usf.edu/gsp/vol9/iss3/17

This Book Review is brought to you for free and open access by the Open Access Journals at Digital Commons @ University of South Florida. It has been accepted for inclusion in Genocide Studies and Prevention: An International Journal by an authorized editor of Digital Commons @ University of South Florida. For more information, please contact digitalcommons@usf.edu. 


\title{
Book Review: Mothering the Fatherland: A Protestant Sisterhood Repents for the Holocaust
}

\author{
Linda F. Burghardt \\ Holocaust Memorial \& Tolerance Center
}

Mothering the Fatherland: A Protestant Sisterhood Repents for the Holocaust

George Faithful

New York, Oxford University Press, 2014

304 pp., US\$78.00 (hbk)

Reviewed by Linda F. Burghardt

Holocaust Memorial \& Tolerance Center

The sins of the German people against God and the Jews -- these eleven words haunted and ultimately dominated the lives of a handful of radical women who, in 1947, banded together in order to repent for the actions of an entire country against a portion of its population and the targeted people throughout Holocaust-era Europe. The women were Lutheran nuns, and they were seeking redemption, not only for themselves but for Germany in all its forms: as a political system, a military complex, as individual people, a religious structure, a culture, even within the very self-concept of its citizens.

Under the leadership of Mother Basilea Schlink, the Sisters sought to bring the idea of national guilt into the awareness of their own Protestant community and ultimately the world. George Faithful, in a rigorous and enlightening foray into their minds and hearts, tells the story of how this happened in Mothering the Fatherland, a new book that embraces and explicates personal theology, Holocaust history, the larger issues of genocide, and even paradigms of self-sacrifice in roughly equal measure.

The immediate impetus for the formation of the Ecumenical Sisters of Mary, as the group was called, was the bombing by the Allies in 1944 of the city of Darmstadt, Germany, in which the Sisters lived. The destruction was viewed as a sign of God's anger; the Sisters were struck with the stark and sudden perception that they personally were being punished for the death of the six million Jews who were murdered in the Holocaust.

Mother Schlink sprang into action, motivated by her belief that she was destined to lead a handful of true Christians in repentance, and that it was up to this small, independent group of women to bring the entire German populace to their knees. She saw the Sisterhood she founded as a group of priests acting on behalf of all the Germans, making spiritual sacrifices so that the larger population would be saved from the imminent destruction she saw looming in the near distance.

Convinced that God was set on destroying Germany for its sins, the Ecumenical Sisters of Mary transcended gender norms by grasping spiritual authority away from the male leaders around them, priests who were imbued by the Church with a power denied to females. Yet the Sisters elevated themselves above them, denying the rules designed to keep them in their place in order to pursue redemption.

The book, called a monograph by the publisher, creates and then ties together several divergent paths at once, engaging the reader in this highly unusual tale. By repenting for the actions of the Nazis, the Sisters make manifest Basilea Schlink's well-defined vision, and while doing so they explain much of the dynamics of $20^{\text {th }}$ century theopolitical history in Germany and ultimately Israel. It is an absorbing journey, and the thoughtful analysis of the Sisterhood's founder is only one aspect of its success, albeit a major one. In another perhaps more significant way, the volume presents a new theory that expands the field of Christian-Zionism studies.

Faithful is a gifted writer, one who documents his work with care and finds language that flows easily around his subject matter. While this is primarily a work of historical theology, its academic yet accessible style will appeal to a wider audience than those embedded in this somewhat narrow discipline. Genocide scholars will find his ideas illuminating, and Holocaust historians will be 
intrigued by his grasp of this small but significant movement among the German populace. Those who are concerned with the development of German Christianity, from its roots to the roiling changes taking place even today, will see patterns and themes here that help them project these concepts into the future.

Overall, anyone engaged in the study of the Holocaust or, by extension, the actions, perorations and motivations of the perpetrators of genocide, will find this book worthwhile. Further, the monograph will appeal to students in each of these academic areas, as it sheds a new light on an area that usually receives scant attention: the mix of German theology and Jewish-Christian relations.

As a case in point, Faithful explains that Mother Schlink's ideas were a direct outgrowth of her deep study of the Hebrew Bible, a fascinating bit of information that brightly illuminates her thinking processes. Her contemplations, combined with her intense interest in German nationalism, resulted in her creation of the basic tenets of the Sisterhood and the penitential practices that held sway over the daily life of the community she directed.

The author's careful explanation of how well Mother Schlink developed her ideas and acted on them, convincing a number of other young women to devote their lives to them, is one of the strong points of the book. Ironically, it seems she worked in miniature to mimic the powerful methods the Nazis used to create a following for their beliefs. This model is applicable not only to understanding the thoughts and actions of religious orders, special interest groups and even nations, but also those of past and future perpetrators of genocide, who use their often remarkable leadership skills to convince their followers to go with them on their sometimes twisted paths.

Faithful's deep understanding of both Jewish and Christian theology and how they interact adds another very positive dimension to the story. He has succeeded in creating a clear picture of German national theology and faith and bringing it together with the historical journey of the Jews, and in this way he arguably makes the largest contribution of this fine volume: illuminating a series of critical developments in post-war Germany through a lens no has looked through in quite the same way before.

Through his close study of this unconventional group of women, he provides the first extensive research about Mother Schlink and the Sisterhood of Mary, beginning in war-torn German in 1947, when they take their vows of poverty, obedience and chastity and make their plans to atone for German guilt for committing the Holocaust. He continues to study them through the years in which they do penance for Christian anti-Semitism.

Most books that try to explain the aftermath of the actions of Germany during the Holocaust focus on the country's inability to repent, often to even admit their guilt for the Holocaust, no less to mourn for all that they have destroyed. But this volume provides a significant counterpoint to this kind of narrative, and because of this it is particularly refreshing and welcome.

Additionally, the author creates his arguments carefully, presenting facts and figures and building up his theses one careful step at a time. This is particularly satisfying when he is attempting to explain the finer points of theopolitical history, for instance, since not all his readers will be wellversed in both Church doctrine and the intricacies of German politics.

For example, when he describes how the Sisters were so deeply distressed by the Holocaust that they were willing to devote their lives to repenting for the sins of the German nation during the Third Reich, he goes into careful detail about not only their religious beliefs but also the national political culture, deftly interweaving the two so that we begin to understand the basis for their sacrifice and lose the disbelief with which most of us will have begun the journey through the book.

Faithful is uniquely well qualified to have written Mothering the Fatherland. He has a doctorate in historical theology from St. Louis University, having earned his B.A. in German and religion from Wake Forest University in Winston-Salem, N.C. He also studied at the Universite de Nantes, and the Humboldt Universität zu Berlin.

His careful attention to detail in the book inspires confidence in his theories, and the evidence of his painstaking research significantly enhances the narrative. For example, the book contains extensive notes documenting the facts and figures upon which the story rests, a well-appointed index, and three appendices that explain not only the underlying beliefs and overall concepts but also the finer workings of the German Protestant Church. He even includes a translation list of 
frequently used German words, so that readers unfamiliar with the language will not become lost in the narrative.

His list of references is a treasure trove to researchers who hope to expand on this topic or delve more deeply into related issues, as it details the archival unpublished primary sources he relied upon, plus both the more typical yet still quite extensive primary and secondary sources. Figures and photographs enhance the book and help drive home his theories and concepts.

It is difficult to try to place Faithful's work in the context of other theological or historical treatises that deal with repentance, since he recognizes that most Protestants held views that fit with many of the basic ideologies of the Nazis, and thus supported their actions relative to the Jews. A comparative study among the few groups that have been discussed would make a fascinating follow-up to this case study.

Overall, Mothering the Fatherland offers a very satisfying experience. The author sets the Sisters' theological beliefs and practices within the context of the history and intellectual currents of the time, so that we gain a deeper understanding of them than we would get from mere exposition. For example, one chapter deals extensively with Mother Schlink's theological views on the differences between Jews and Germans, categories she saw as mutually exclusive, which was exactly how most German nationalists saw the divide. Yet viewing the Jews through her eyes goes a long way toward explaining much of her motivation in forming the Sisters of Mary. Still, Faithful emphasizes that Mother Schlink perceived the Jews as inhabiting the place of greater value between the two, demonstrating that she was not only an anti-Nazi theologian but actually an admirer of the people her nation had tried to destroy. 